\title{
Year-to-Year Incidence of Cranberry Fruit Rot and Persistence of Fungal Pathogens
}

\author{
Lindsay D. Wells-Hansen and Patricia S. McManus, Department of Plant Pathology, University of Wisconsin-Madison, Madison 53706
}

Accepted for publication 17 April 2017.

\begin{abstract}
Cranberry fruit rot is a disease complex comprised of as many as 15 fungal species. Current management recommendations are to spray broad-spectrum fungicides every year in regions such as New Jersey where fruit rot incidence is high on a consistent basis. By contrast, in regions such as Wisconsin, where economic losses from fruit rot occur sporadically, many growers forego fungicide sprays, but if faced with a serious fruit rot outbreak they then spray fungicides intensively the following year to prevent a recurrence of disease. This recommendation is based on the untested assumption that left unchecked, fruit rot incidence will

increase and that the predominant fruit rot pathogens will persist from one year to the next. Field studies conducted over 3 years showed that in New Jersey fruit rot incidence increased or remained high and fruit rot pathogens persisted from one year to the next. By contrast, in Wisconsin fruit rot incidence decreased or remained low, and the persistence of pathogens was inconsistent from one year to the next. Thus, in Wisconsin, fruit rot incidence and fungal species present in one year do not reliably predict the disease situation in the following year, a finding that should be considered when planning fungicide spray programs.
\end{abstract}

The large American cranberry (Vaccinium macrocarpon Aiton) is native to parts of eastern North America, with domestication first taking place in the northeastern United States in the nineteenth century (Stiles and Oudemans 1999). In the early days of cranberry production, fruit rot was the most important disease, noticeably reducing yields after just 5 to 10 years of production (Oudemans et al. 1998). Cranberry fruit rot remains one of the greatest challenges to the industry, and in some growing regions, crop losses reach $100 \%$ if fruit rot is left unchecked (Oudemans et al. 1998; Polashock et al. 2009). Cranberry fruit rot is a disease complex comprised of as many as 15 fungal pathogens (Oudemans et al. 1998; Polashock et al. 2017). While there is extensive variability in the severity of fruit rot among and within growing regions (McManus et al. 2003; Olatinwo et al. 2003; Oudemans et al. 1998), the principal pathogens that comprise the fruit rot complex (Colletotrichum fioriniae, Colletotrichum gloeosporioides, Coleophoma empetri, Phomopsis vaccinii, and Physalospora vaccinii) are present across all regions (Polashock et al. 2009).

Although sources of partial resistance to fruit rot have been identified, all commercially relevant cultivars are susceptible to the fruit rot complex (Johnson-Cicalese et al. 2015). Therefore, most growers apply fungicides to prevent crop loss and to keep plantings productive for several decades. While detailed disease cycles for all of the pathogens involved in the fruit rot complex have not been described, research suggests that these fungi infect cranberry plants primarily during bloom and early fruit set stages (Oudemans et al. 1998); once cranberry fruit develop rot symptoms, it is too late for fungicides to provide any benefit in that growing season. In regions with high fruit rot pressure, such as Massachusetts and New Jersey, growers typically apply fungicides three to five times annually, starting during early bloom, to prevent crop loss. However, even

Corresponding author: Patricia S. McManus; E-mail: psm@plantpath.wisc.edu

(C) 2017 The American Phytopathological Society when multiple, carefully timed fungicide applications are made, crop losses of approximately $25 \%$ are not uncommon in New Jersey (Johnson-Cicalese et al. 2015). In Wisconsin, fruit rot is sporadic and its severity varies widely among years and locations (McManus et al. 2003; Wells et al. 2014), making it difficult to recommend appropriate fungicide spray programs. Because fruit rot is not an inevitable threat in Wisconsin, many growers forego annual fungicide applications, but then if faced with a severe outbreak, they spray broad-spectrum fungicides intensively the following year. This practice is based on the assumption that pathogens will persist at high levels over winter, creating high disease pressure in the year following a fruit rot outbreak. However, no research has been performed to validate the basis for this approach to fruit rot management.

Historically, cranberry growers have relied on broad-spectrum fungicides such as chlorothalonil and mancozeb for control of fruit rot pathogens (Oudemans et al. 1998; Wells et al. 2014). However, these fungicides carry human health and environmental risks, prompting the cranberry industry to shift toward other classes of fungicides, especially strobilurins (azoxystrobin and fluoxastrobin) and sterol demethylation inhibitors (fenbuconazole and prothioconazole) for fruit rot control. We previously demonstrated that some of these more recently registered fungicides (e.g., fenbuconazole) exhibit specificity for cranberry fruit rot pathogens (Wells et al. 2014). Based on those findings, we recommend that growers submit samples for diagnosis to determine which fungi are most prevalent on their farms, especially in beds with recurrent fruit rot, so that the most appropriate fungicides can be deployed for fruit rot control. This recommendation, however, is based on the untested assumption that the fungal species isolated from rotten fruit in one year will persist over winter and be important in the following growing season.

In the present study we tested the hypothesis that cranberry fruit rot incidence (i.e., the percentage of rotten fruit in a sample) and the fungal pathogens present do not differ from one year to the next. 
Because fruit rot incidence and the frequency of fruit rot pathogens are highly variable within cranberry beds (McManus et al. 2003), we designed experiments to track incidence and presence of fungal pathogens in defined plots within beds from one year to the next. The objectives were to: (i) monitor changes in cranberry fruit rot incidence across years; and (ii) determine the persistence of individual cranberry fruit rot pathogens across years.

\section{Fruit Rot Incidence Across Years}

Trials were conducted in five cranberry beds at the Philip E. Marucci Blueberry and Cranberry Research Station near Chatsworth, NJ (Table 1) and two beds at each of two commercial farms near Oakdale and Tomah, WI (Table 2). In each bed, 4 or 12 plots measuring $0.8 \mathrm{~m}^{2}$ were staked and sampled in 2013 and sampled again in 2014 and 2015 to track fruit rot incidence from the same plots across years. A total of 20 plots in New Jersey and 32 plots in Wisconsin was sampled (Tables 1 and 2). In New Jersey, two beds of cultivar Crimson Queen were not sampled in 2015 because of inadequate berry numbers. In Wisconsin, a bed of cultivar Stevens was not sampled in 2013 because the grower harvested the crop

\begin{tabular}{|c|c|c|c|}
\hline \multicolumn{4}{|c|}{$\begin{array}{l}\text { TABLE } 1 \\
\text { Cranberry fruit rot incidence at one farm in Chatsworth, } \\
\text { New Jersey }\end{array}$} \\
\hline \multirow[b]{2}{*}{ Plot $^{\mathbf{b}}$} & \multicolumn{3}{|c|}{ Fruit rot incidence $(\%)^{a}$} \\
\hline & 2013 & 2014 & 2015 \\
\hline ST1A & 50 & 80 & 81 \\
\hline ST1B & 59 & 78 & 76 \\
\hline ST1C & 66 & 84 & 91 \\
\hline ST1D & 49 & 76 & 80 \\
\hline Mean & 56 & 79 & 82 \\
\hline ST2A & 81 & 77 & 84 \\
\hline ST2B & 76 & 72 & 85 \\
\hline ST2C & 83 & 87 & 78 \\
\hline ST2D & 81 & 75 & 75 \\
\hline Mean & 80 & 78 & 80 \\
\hline CQ1A & 40 & 86 & $-^{\mathrm{c}}$ \\
\hline CQ1B & 40 & 85 & - \\
\hline CQ1C & 43 & 88 & - \\
\hline CQ1D & 34 & 85 & - \\
\hline Mean & 39 & 86 & - \\
\hline CQ2A & 86 & 97 & - \\
\hline CQ2B & 26 & 91 & - \\
\hline CQ2C & 66 & 87 & - \\
\hline CQ2D & 59 & 88 & - \\
\hline Mean & 60 & 91 & - \\
\hline CQ3A & 100 & 99 & 80 \\
\hline CQ3B & 100 & 100 & 90 \\
\hline CQ3C & 100 & 99 & 88 \\
\hline CQ3D & 100 & 100 & 86 \\
\hline Mean & 100 & 99 & 86 \\
\hline
\end{tabular}

${ }^{\text {a }}$ For each plot, fruit rot incidence ([no. rotten berries/total no. berries] $\times$ 100 ) was determined in a sample (approximately $600 \mathrm{~g}$ ) of fruit. Incidence increased from 2013 to $2014(P=0.0007)$ and decreased from 2014 to $2015(P=0.018)$.

${ }^{\mathrm{b}}$ Cultivars were Stevens (ST) and Crimson Queen (CQ). There were two Stevens beds and three Crimson Queen beds, each with four plots. Plots within a bed are indicated by letters. All beds were established in 2006.

${ }^{\mathrm{c}}$ In 2015, berries were not collected from Crimson Queen beds 1 and 2. early. Because not every plot was sampled in every year, there was a total of 32 and 52 year-to-year comparisons performed in New Jersey and Wisconsin, respectively. Beds were treated with insecticides, herbicides, fertilizers, and water as needed to manage the crop (Guédot et al. 2016; Laboski and Peters 2012), but fungicides were not applied to test areas of the beds during 2013, 2014, or 2015. Fruit from each $0.8-\mathrm{m}^{2}$ plot was harvested by hand just prior to commercial harvest in each year, which ranged from 12 September to 12 October. For each plot, a sample (approximately 600 to

\begin{tabular}{|c|c|c|c|c|}
\hline \multicolumn{5}{|c|}{$\begin{array}{c}\text { TABLE } 2 \\
\text { Cranberry fruit rot incidence at two farms in Wisconsin }\end{array}$} \\
\hline \multirow[b]{2}{*}{ Farm location } & \multirow[b]{2}{*}{ Plot $^{\mathbf{b}}$} & \multicolumn{3}{|c|}{ Fruit rot incidence $(\%)^{a}$} \\
\hline & & 2013 & 2014 & 2015 \\
\hline \multirow[t]{10}{*}{ Oakdale } & GH1-1A & 30 & 13 & 3 \\
\hline & GH1-1B & 37 & 10 & 5 \\
\hline & GH1-1C & 21 & 15 & 3 \\
\hline & GH1-1D & 9 & 8 & 5 \\
\hline & Mean & 24 & 12 & 4 \\
\hline & GH1-2A & 9 & 8 & 3 \\
\hline & GH1-2B & 10 & 6 & 3 \\
\hline & GH1-2C & 19 & 24 & 7 \\
\hline & GH1-2D & 25 & 36 & 8 \\
\hline & Mean & 16 & 19 & 5 \\
\hline \multirow{26}{*}{ Tomah } & GH1A & 4 & 3 & 2 \\
\hline & GH1B & 4 & 3 & 2 \\
\hline & GH1C & 5 & 4 & $<1$ \\
\hline & GH1D & 5 & 2 & 3 \\
\hline & GH1E & 4 & 5 & 2 \\
\hline & GH1F & 3 & 5 & 5 \\
\hline & GH1G & 3 & 4 & 2 \\
\hline & GH1H & 5 & 8 & 2 \\
\hline & GH1I & 3 & 4 & 2 \\
\hline & GH1J & 3 & 2 & 3 \\
\hline & GH1K & 4 & 2 & 3 \\
\hline & GH1L & 3 & 3 & 1 \\
\hline & Mean & 4 & 4 & 2 \\
\hline & STA & $-^{c}$ & 19 & 2 \\
\hline & STB & - & 30 & 1 \\
\hline & STC & - & 8 & 1 \\
\hline & STD & - & 13 & $<1$ \\
\hline & STE & - & 12 & 1 \\
\hline & STF & - & 12 & 1 \\
\hline & STG & - & 2 & 1 \\
\hline & STH & - & 13 & 2 \\
\hline & STI & - & 2 & 1 \\
\hline & STJ & - & 6 & 1 \\
\hline & STK & - & 3 & 1 \\
\hline & STL & - & 7 & 1 \\
\hline & Mean & - & 11 & 1 \\
\hline
\end{tabular}

${ }^{\mathrm{a}}$ For each plot, fruit rot incidence ([no. rotten berries/total no. berries] $\times$ 100) was determined in a sample (approximately 600 to $1200 \mathrm{~g}$ ) of fruit. Fruit rot incidence did not differ from 2013 to $2014(P=0.8797)$, but decreased from 2014 to $2015(P=0.0001)$.

${ }^{\mathrm{b}}$ Cultivars were Grygleski Hybrid \#1 (GH1) and Stevens (ST). There were two Grygleski Hybrid \#1 beds (established prior to 2007) at the Oakdale farm, each with four plots. There was one Grygleski Hybrid \#1 bed (established in 2008) and one Stevens bed (established in 2005) at the Tomah farm, each with 12 plots. Plots within a bed are indicated by letters.

${ }^{\mathrm{c}}$ In 2013, berries were not collected from the Stevens bed at the Tomah farm. 
$1200 \mathrm{~g}$ ) of fruit was sorted into three categories: sound, marketable berries; soft, rotten berries; or berries that were unmarketable for reasons other than fruit rot, such as insect damage. For each sample, berries in each category were counted to determine fruit rot incidence ([no. rotten berries/total no. berries] $\times 100$ ). Fruit rot incidence was analyzed separately for each state using the Mixed Procedure (SAS Version 9.4, SAS Institute, Inc., Cary, NC). Based on an examination of residuals, the dependent variable, percent fruit rot, was transformed using an arcsine square-root transformation to correct for nonnormality. In keeping with the experimental design, the experiment was analyzed as a mixed effects model with nested experimental units. Specifically, each farm was considered to be a block. Within blocks, there were beds, and the treatment for each bed was the cultivar. As described above, plots were nested in each bed, and from each plot a sample was taken each year. The beds and plots were modeled as (nested) random effects; cultivar and year were modeled as fixed effects. This resulted in the measurements from year to year being modeled as repeated measurements with an assumed compound symmetry correlation over time. Fisher's protected least significant difference was used to compare least squares means of year effects.

Fruit rot incidence varied between states, and among years, beds, and plots within a bed (Tables 1 and 2). In New Jersey, average fruit rot incidence increased significantly from 2013 to $2014(P=$ $0.0007)$ and decreased significantly from 2014 to $2015(P=0.018)$, although despite the statistically significant decrease, the incidence of fruit rot in 2015 remained high (Table 1). Also, the relatively small number of comparisons from 2014 to 2015 limits the conclusions that can be drawn. On an individual plot basis, incidence increased by at least $5 \%$, decreased by at least $5 \%$, or remained within $5 \%$ from one year to the next in 15,6 , and 11 of 32 year-toyear comparisons, respectively. For the comparisons in New Jersey in which fruit rot incidence remained within $5 \%$ from one year to the next, incidence was at least $72 \%$. In Wisconsin, average fruit rot incidence did not differ significantly from 2013 to $2014(P=$ $0.8797)$, but decreased significantly from 2014 to $2015(P=0.0001)$ (Table 2). On an individual plot basis, incidence increased by at least $5 \%$, decreased by at least $5 \%$, or remained within $5 \%$ from one year to the next in 2, 19, and 31 of 52 year-to-year comparisons, respectively. For the comparisons in Wisconsin in which fruit rot incidence remained within $5 \%$ from one year to the next, incidence was $10 \%$ or lower. These findings corroborate previous reports: in New Jersey, fruit rot incidence increased in a stepwise fashion from one year to the next (Oudemans et al. 1998) when no fungicides were applied, while in Michigan (Olatinwo et al. 2003) and Wisconsin (Jeffers 1991), incidence fluctuated in plots not treated with fungicides over 3-year periods in each study.

\section{Persistence of Fruit Rot Pathogens Across Years}

At least 20 rotten berries were arbitrarily selected from the fruit harvested from each plot except the plots at Tomah, WI, in 2015, in which disease incidence was too low to obtain adequate numbers of rotten berries. Whole berries were surface disinfested for $5 \mathrm{~min}$ in a $10 \%$ household bleach solution ( $0.6 \%$ sodium hypochlorite) containing one drop (approximately $3 \mu \mathrm{l}$ ) Tween 20 per $100 \mathrm{ml}$ of solution. Berries were then rinsed in sterile distilled water and sliced in half transversely. Each cranberry half was placed cut-side down on a $90-\mathrm{mm}$ diameter Petri plate containing potato dextrose agar ( $24 \mathrm{~g}$ potato dextrose broth, $16 \mathrm{~g}$ agar, and $1,000 \mathrm{ml}$ distilled water) amended with streptomycin sulfate $(100 \mu \mathrm{g} / \mathrm{ml})$ to prevent bacterial growth. Plates with berries were incubated at room temperature (20 to $25^{\circ} \mathrm{C}$ ) for 2 weeks under indirect fluorescent light. After 2 weeks, the fungi growing from each berry were identified based on colony morphology, spore characteristics, and fruiting bodies (Polashock et al. 2017; Wells and McManus 2013).

Analysis of presence or absence of the five principal cranberry fruit rot fungi was on a per-plot basis and done separately for New Jersey and Wisconsin. Because cultivar was previously shown to not influence the profile of fungal pathogens in rotten fruit (Stiles and Oudemans 1999), data were combined over cultivars for each state. The proportion of plots that contained at least one rotten berry yielding a particular fungal species was compared across years (2013 to 2014 and 2014 to 2015), and differences in the presence of a fungal species in a plot from year to year were assessed using the McNemar test (McNemar 1947). For McNemar tests, $P>0.05$ indicated no difference between years in the proportion of plots yielding a given pathogen. When the proportion of plots yielding a fungal species was large in consecutive years and $P>0.05$, then that species was considered to persist at high levels across years. When the proportion of plots yielding a fungal species was small in consecutive years and $P>0.05$, then that species was considered to persist at low levels across years. By contrast, $P<0.05$ indicated a difference in the proportion of plots yielding a given pathogen. Although several studies (Jeffers 1991; McManus et al. 2003; Polashock et al. 2009; Stiles and Oudemans 1999; Zuckerman 1958) have investigated the distribution and frequency of cranberry fruit rot pathogens in the major growing regions, this study is the first to quantify the persistence of fungi in defined plots over years. This approach was taken in an attempt to minimize the variability in both fruit rot incidence and fungal species encountered when berries are collected from randomly assigned plots in beds (McManus et al. 2003) and to better track the fate of individual fungal species.

In New Jersey, the most frequently isolated pathogens were Colletotrichum gloeosporioides and Physalospora vaccinii (Tables 3 and 4), consistent with previous findings in that state (Stiles and Oudemans 1999). Colletotrichum gloeosporioides and Physalospora vaccinii were persistent at high levels, while Coleophoma empetri and Colletotrichum fioriniae were persistent at low or moderate levels from one growing season to the next, and Phomopsis vaccinii was not isolated (Table 4). In Wisconsin, the dominant pathogens varied among years (Tables 4 and 5), consistent with previous findings in that state (McManus et al. 2003; Wells et al. 2014). In Wisconsin, Coleophoma empetri was the only persistent fungal species from 2013 to 2014, but all of the principal fruit rot pathogens were persistent at low to high levels from 2014 to 2015 (Table 4). When there was a difference in the proportion of plots yielding a particular fungal species (i.e., when $P<0.05$ ), the proportion was always smaller in the second year of the contrast, indicating a diminution of that pathogen from 2013 to 2014. In both New Jersey and Wisconsin, several other fungi, including members of the genera Trichoderma, Alternaria, Pestalotia, and Epicoccum, as well as unidentified fungi, were isolated from approximately 30 to $70 \%$ of berries. These genera are among "fungi with uncertain pathogenicity" (Oudemans et al. 1998), and we cannot rule out the possibility that one or more of them or unidentified fungi could have contributed to the rot observed.

\section{Implications for Disease Management}

Cranberry fruit rot previously (Oudemans et al. 1998) has been described to behave as a simple interest disease (sensu Vanderplank [1963]), in which disease increases in a stepwise manner from one year to the next in the absence of control measures. Our findings suggest that this indeed was the case at the New Jersey site, where incidence generally increased or remained steadily high from one 


\begin{tabular}{|c|c|c|c|c|c|c|c|c|c|c|c|c|c|c|c|}
\hline \multirow[b]{4}{*}{ Plot $^{\mathbf{b}}$} & \multicolumn{15}{|c|}{$\begin{array}{l}\text { TABLE } 3 \\
\text { Recovery of the principal cranberry fruit rot pathogens across years in New Jersey }\end{array}$} \\
\hline & \multicolumn{15}{|c|}{ Percent of berries yielding cranberry fruit rot pathogen ${ }^{a}$} \\
\hline & \multicolumn{3}{|c|}{$\begin{array}{l}\text { Colletotrichum } \\
\text { fioriniae }\end{array}$} & \multicolumn{3}{|c|}{$\begin{array}{l}\text { Colletotrichum } \\
\text { gloeosporioides }\end{array}$} & \multicolumn{3}{|c|}{$\begin{array}{l}\text { Coleophoma } \\
\text { empetri }\end{array}$} & \multicolumn{3}{|c|}{$\begin{array}{l}\text { Phomopsis } \\
\text { vaccinii }\end{array}$} & \multicolumn{3}{|c|}{$\begin{array}{l}\text { Physalospora } \\
\text { vaccinii }\end{array}$} \\
\hline & 2013 & 2014 & 2015 & 2013 & 2014 & 2015 & 2013 & 2014 & 2015 & 2013 & 2014 & 2015 & 2013 & 2014 & 2015 \\
\hline ST1A & 5 & 15 & 15 & 60 & 90 & 65 & 10 & 10 & 0 & 0 & 0 & 0 & 15 & 35 & 15 \\
\hline ST1C & 10 & 0 & 0 & 95 & 100 & 70 & 10 & 0 & 15 & 0 & 0 & 0 & 15 & 15 & 20 \\
\hline ST1D & 10 & 5 & 0 & 80 & 100 & 50 & 5 & 25 & 5 & 0 & 0 & 0 & 20 & 30 & 35 \\
\hline ST2A & 0 & 0 & 0 & 90 & 95 & 55 & 30 & 25 & 5 & 0 & 0 & 0 & 30 & 25 & 25 \\
\hline ST2B & 0 & 5 & 0 & 90 & 100 & 65 & 35 & 20 & 5 & 0 & 0 & 0 & 55 & 40 & 15 \\
\hline ST2C & 0 & 5 & 10 & 90 & 90 & 50 & 5 & 15 & 5 & 0 & 0 & 0 & 40 & 55 & 55 \\
\hline CQ1B & 0 & 0 & - & 75 & 95 & - & 0 & 0 & - & 0 & 0 & - & 25 & 25 & - \\
\hline CQ1C & 5 & 0 & - & 65 & 75 & - & 0 & 0 & - & 0 & 0 & - & 30 & 45 & - \\
\hline CQ1D & 0 & 0 & - & 65 & 80 & - & 0 & 0 & - & 0 & 0 & - & 30 & 55 & - \\
\hline CQ2A & 0 & 0 & - & 75 & 75 & - & 0 & 0 & - & 0 & 0 & - & 45 & 50 & - \\
\hline CQ2B & 0 & 5 & - & 65 & 80 & - & 0 & 0 & - & 0 & 0 & - & 80 & 30 & - \\
\hline CQ2C & 0 & 5 & - & 65 & 85 & - & 0 & 0 & - & 0 & 0 & - & 60 & 35 & - \\
\hline CQ2D & 0 & 0 & - & 50 & 80 & - & 0 & 0 & - & 0 & 0 & - & 15 & 15 & - \\
\hline CQ3A & 0 & 0 & 0 & 55 & 75 & 50 & 0 & 0 & 0 & 0 & 0 & 0 & 35 & 95 & 0 \\
\hline CQ3B & 0 & 15 & 5 & 55 & 85 & 75 & 0 & 0 & 0 & 0 & 0 & 0 & 45 & 25 & 0 \\
\hline
\end{tabular}

${ }^{\text {a }}$ For each plot, fungal pathogens were isolated from 20 rotten berries.

${ }^{\mathrm{b}}$ Samples were collected from two beds of cultivar Stevens (ST1 and ST2) and three beds of Crimson Queen (CQ1, CQ2, and CQ3). Plots within a bed are indicated by letters.

${ }^{\mathrm{c}}$ In 2015, berries were not collected from Crimson Queen beds 1 and 2.

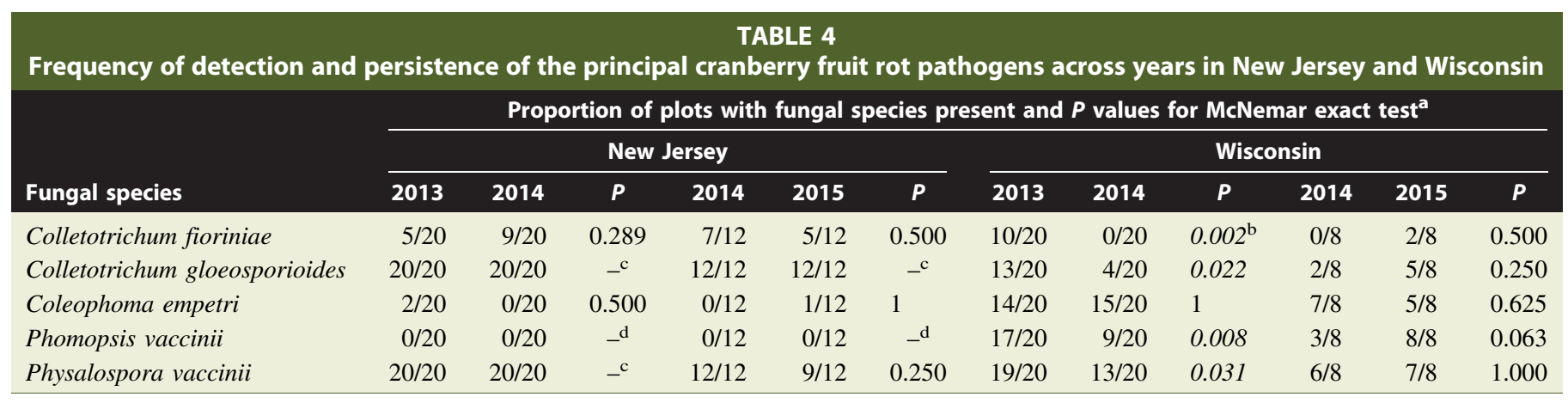

${ }^{\text {a }} P<0.05$ indicates a difference between years in the proportion of plots from which a given fungal species was recovered from rotten berries. $P>0.05$ indicates no difference between years in the proportion of plots from which a given fungal species was recovered from rotten berries.

b Values in italics are significant $(P<0.050)$.

${ }^{\mathrm{c}}$ These fungal species were recovered from all plots in both years being compared; therefore, a presence/absence comparison could not be made, and no $P$ value was obtained. These species are considered persistent across years.

${ }^{\mathrm{d}}$ Phomopsis vaccinii was not recovered from any New Jersey plots in any year; therefore, a presence/absence comparison could not be made, and no $P$ value was obtained.

year to the next. Clearly, annual fungicide application is warranted in such situations. In Wisconsin, however, average fruit rot incidence either decreased or remained low from one year to the next. Also, on an individual plot basis, fruit rot incidence increased by more than $5 \%$ in just two of 52 year-to-year comparisons in the absence of fungicide applications. The reason for a difference in year-to-year fruit rot dynamics between the states is not clear, but the consistently higher temperatures in New Jersey compared with 


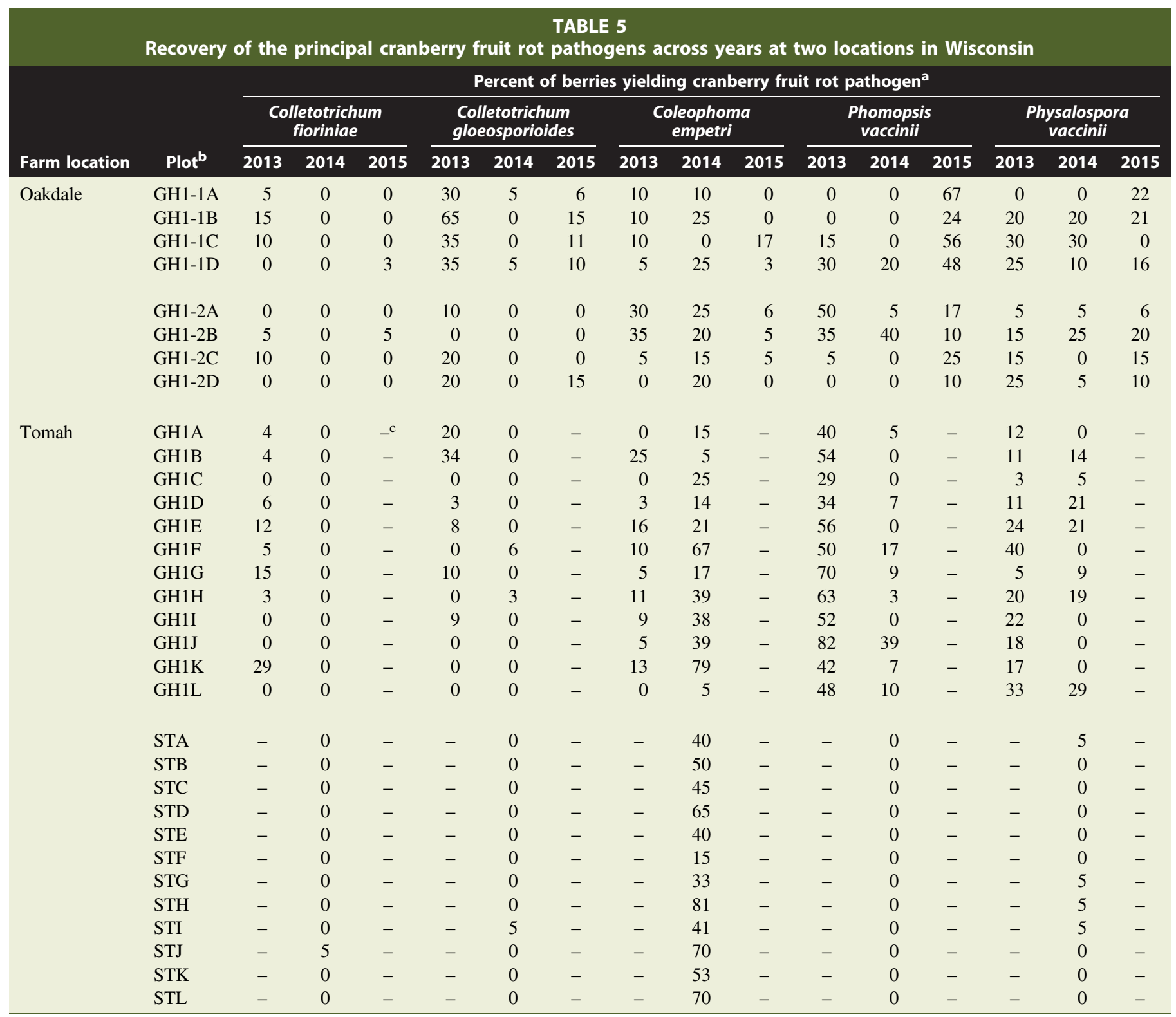

${ }^{\text {a }}$ For each plot, fungal pathogens were isolated from at least 20 rotten berries.

${ }^{\mathrm{b}}$ Samples were collected from two beds of cultivar Grygleski Hybrid \#1 (GH1-1 and GH1-2) at Oakdale and from one bed each of cultivars GH1 and Stevens (ST) at Tomah. Plots within a bed are indicated by letters.

${ }^{\mathrm{c}}$ Berries were not collected from the Stevens bed at Tomah in 2013, and fungi were not isolated from berries collected from either bed at Tomah in 2015 due to low fruit rot incidence.

Wisconsin are presumed to favor rot development on an annual basis. In sum, our findings suggest that in Wisconsin, fruit rot incidence in one year is not a good predictor of incidence in the following year. Thus, the current strategy in Wisconsin of intensifying spray programs the year following a severe fruit rot outbreak, although conservative from a disease loss standpoint, likely results in unnecessary fungicide use.

Current recommendations in Wisconsin are that growers who experience a severe outbreak of fruit rot should have berries tested to determine if pathogens are present, and if so, which pathogen(s) predominate. With this information, a grower then can choose fungicides for the following year that are effective in controlling the identified pathogen(s). The results of the current study suggest that this approach is suitable for farms such as the New Jersey site, where predominant pathogens persisted at a high level from one season to the next. In Wisconsin, however, the persistence of pathogens from one year to the next was inconsistent. This situation makes it difficult to advise growers on using newer fungicides that are considered safer for the environment and humans than chlorothalonil and mancozeb, but that have gaps in their efficacy toward fungal species in the fruit rot disease complex.

Our study focused on sites in New Jersey and Wisconsin with a past history of fruit rot and was limited to just two cultivars in each state. Although cultivar was earlier shown to not affect the frequency of various fungal species isolated from rotten fruit (Stiles and Oudemans 1999), two cultivars used in the current study, Crimson Queen and Grygleski Hybrid \#1, are relatively new and were not included in the earlier study. We directed sampling effort within sites rather than collecting samples from several sites because 80 to $91 \%$ of the variability in fruit rot incidence in Wisconsin 
was previously attributed to samples within a site (McManus et al. 2003). Nevertheless, the relatively small number of sites included in this study should be considered when interpreting results. While the 3 -year duration of our study is equal to or longer than most previously published field studies on cranberry fruit rot, additional year-to-year comparisons would improve confidence in disease management recommendations. Notwithstanding these limitations, our study has provided additional data to support the annual application of fungicides in New Jersey and highlights the need to identify critical cultural and environmental factors that contribute to fruit rot in Wisconsin. With such information, growing practices might be modified and fruit rot prediction systems developed with the goal of reducing fungicide inputs to enhance the sustainability and profitability of cranberry production.

\section{Acknowledgments}

We thank our cranberry grower-cooperators as well as P. Oudemans and the Philip E. Marucci Center for Blueberry and Cranberry Research for the use of field sites. We also thank A. Cramer for assistance with sample collection and M. Clayton for data analysis and helpful discussions. This research was funded by the National Institute of Food and Agriculture, United States Department of Agriculture, under ID number WIS01653, Vaughan-Bascom Professorship of the Department of Plant Pathology, University of Wisconsin-Madison, and the Senator Robert Caldwell Graduate Fellowship of the College of Agricultural and Life Sciences, University of Wisconsin-Madison.

\section{Literature Cited}

Guédot, C., McManus, P., Colquhoun, J., and Nice, G. 2016. Cranberry pest management in Wisconsin-2016. Coop. Ext. Publ. A3276. Univ. of Wisconsin, Madison.
Jeffers, S. N. 1991. Effects of fungicides applied during bloom on yield, yield components, and storage rots of cranberry. Plant Dis. 75:244-250.

Johnson-Cicalese, J., Polashock, J. J., Honig, J. A., Vaiciunas, J., Ward, D. L., and Vorsa, N. 2015. Heritability of fruit rot resistance in American cranberry. J. Am. Soc. Hortic. Sci. 140:233-242.

Laboski, C. A. M., and Peters, J. B. 2012. Nutrient application guidelines for field, vegetable, and fruit crops in Wisconsin-2012. Coop. Ext. Publ. A3276. Univ. of Wisconsin, Madison.

McManus, P. S., Caldwell, R. W., Voland, R. P., Best, V. M., and Clayton, M. K. 2003. Evaluation of sampling strategies for determining incidence of cranberry fruit rot and fruit rot fungi. Plant Dis. 87:585-590.

McNemar, Q. 1947. Note on the sampling error of the difference between correlated proportions or percentages. Psychometrika 12:153-157.

Olatinwo, R. O., Hanson, E. J., and Schilder, A. M. C. 2003. A first assessment of the cranberry fruit rot complex in Michigan. Plant Dis. 87:550-556.

Oudemans, P. V., Caruso, F. L., and Stretch, A. W. 1998. Cranberry fruit rot in the Northeast: A complex disease. Plant Dis. 82:1176-1184.

Polashock, J. J., Caruso, F. L., Averill, A. L., and Schilder, A. C. 2017. Compendium of Blueberry, Cranberry, and Lingonberry Diseases and Pests. American Phytopathological Society, St. Paul, MN.

Polashock, J. J., Caruso, F. L., Oudemans, P. V., McManus, P. S., and Crouch, J. A. 2009. The North American cranberry fruit rot fungal community: A systematic overview using morphological and phylogenetic affinities. Plant Pathol. 58:1116-1127.

Stiles, C. M., and Oudemans, P. V. 1999. Distribution of cranberry fruit rotting fungi in New Jersey and evidence for nonspecific host resistance. Phytopathology 89:218-225.

Vanderplank, J. E. 1963. Plant Diseases, Epidemics and Control. Academic Press, Inc., New York.

Wells, L. D., and McManus, P. S. 2013. A photographic diagnostic guide for identification of the principal cranberry fruit rot pathogens. Online. Plant Health Prog. doi:10.1094/PHP-2013-0729-01-DG

Wells, L. D., Perry, R. S., and McManus, P. S. 2014. Fungicide efficacy and specificity toward fungi in the cranberry fruit rot disease complex. Plant Health Prog. 15:31-35.

Zuckerman, B. M. 1958. Relative importance of cranberry fruit rot fungi during the storage and harvest seasons in Massachusetts. Plant Dis. Rep. 42: 1214-1221. 